\title{
PROKARYOTIC DIVERSITY OF HOT SPRINGS IN BALIKESIIR AND KÜTAHYA, TURKEY
}

\author{
ÇELIKKOĞLU, E. - YILMAZ CANKILIÇ, M. ${ }^{*}$ \\ Anadolu University, Faculty of Sciences, Department of Biology, Eskisehir, Turkey \\ (phone: 090-335-05-80/4713; fax: 090-320-49-10) \\ *Corresponding author \\ e-mail: meralyilmaz@anadolu.edu.tr \\ (Received $2^{\text {nd }}$ Jul 2016; accepted $12^{\text {th }}$ Sep 2016)
}

\begin{abstract}
The prokaryotic diversity of the hot springs Sindırg1, Güre, and Havran in the Balıkesir Province and Eynal in the Kütahya Province, both located in the western part of central Anatolia, was analyzed and compared using cultivation and cultivation-independent methods, including Fluorescence In Situ Hybridization (FISH) and cloning of PCR-amplified fragments of 16S rRNA genes. A total of 66 isolates were obtained from the cultures. They were identified to the species or genus level as Geobacillus, Bacillus, Brevibacillus, Aneurinibacillus, Anoxybacillus, and Aeribacillus. As a result of the FISH study, only bacteria domain signals were received, but arkea domain signals were not. A total of 265 clones from the 16S rRNA gene library were analyzed with Amplified Ribosomal DNA Restriction Analysis. These bacterial clones were identified as the genera Anoxybacillus, Meiothermus, Uncultured bacterium, Aneurinibacillus, Brevibacillus, Bacillus, and Geobacillus. This research highlights the prokaryotic diversity of hot springs in the Balıkesir and Kütahya Provinces.
\end{abstract}

Keywords: thermophilic bacteria, $16 \mathrm{~S}$ rRNA, cloning, FISH, ARDRA

\section{Introduction}

Waters that are located near the magma layer, formed by the heating of groundwater, and disturbed on the fault line are called hot springs. Turkey is one of seven countries in the world that are rich in hot springs, with almost 1300 thermal springs throughout Anatolia (Akkaya and Kıvanç, 2002). Nowadays, thermophilic bacteria have significance due to their characteristic enzymes that resist high temperatures and biogas production by decomposition (Kardos et al., 2011). Hyperthermophile enzymes such as amylase, xylenase, protease enzymes, and DNA polymerase from thermophiles are extremely important in industrial areas and genetic engineering research. Therefore, demonstrating the microbial properties of thermal springs is important for industry and the economy. For this reason, studies on the discovery of microorganisms and new enzymes have become more common (Rifaat et al., 2005; Demirjian et al., 2001).

The Balıkesir and Kütahya Provinces are located in western Turkey, which are both well known for their hot springs. Several springs in different regions of these provinces have been known to geologists for many years. However, their prokaryotic diversity has not been explored with molecular phylogenetic approaches.

In the present study, we have used the 16S rRNA methodology to determine the prokaryotic community structure of some of the most popular hot springs of Balikesir and Kütahya: Sindirg1 $\left(93^{\circ} \mathrm{C}\right)$, Güre $\left(65^{\circ} \mathrm{C}\right)$, Havran $\left(62^{\circ} \mathrm{C}\right)$, and Eynal $\left(70^{\circ} \mathrm{C}\right)$. 


\section{Materials and Methods}

\section{Isolation and morphological determination of cultures}

Four hot springs were analyzed (Figure 1,2). Water samples were collected with sterile glass bottles during February and August 2014. Samples were brought to the laboratory on the same day. For inoculation, 1 liter of each sample was filtered with 0.2$\mu \mathrm{m}$ pore size sterilized filters, which were placed in a $0.2 \%$ Nutrient broth (Sigma Aldrich) and Low Phosphate Basal Medium (LPBM). It contained the following, in grams per liter: $\mathrm{NH}_{4} \mathrm{Cl}, 1.0 ; \mathrm{KH}_{2} \mathrm{PO}_{4}, 1.0 ; \mathrm{Na}_{2} \mathrm{HPO}_{4}$. $7 \mathrm{H}_{2} 0,0.1 ; \mathrm{MgSO}_{4} .7 \mathrm{H}_{2} 0,0.2$; $\mathrm{CaCl}_{2} .2 \mathrm{H}_{2} \mathrm{O}, 0.2$; and yeast extract 1.0 ). It was then left at $55^{\circ} \mathrm{C}$ and $70^{\circ} \mathrm{C}$ for several weeks until active biomass became visible. After this, it was purified. Gram staining was applied to isolates and morphological properties were determined with an OLYMPOS BX50 light microscope.
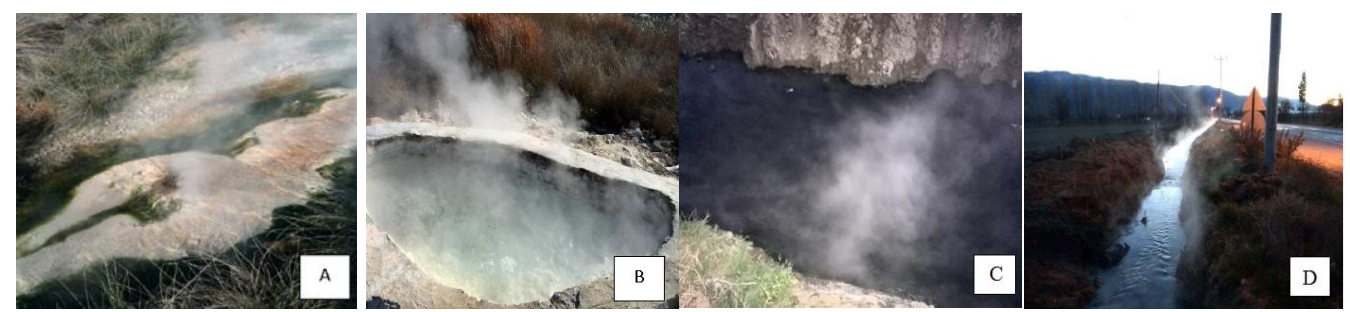

Figure 1. The hot spring Sindırgı in Balıkesir (A, B) and hot springs Güre $(C)$ and Eynal $(D)$ in Kütahya.

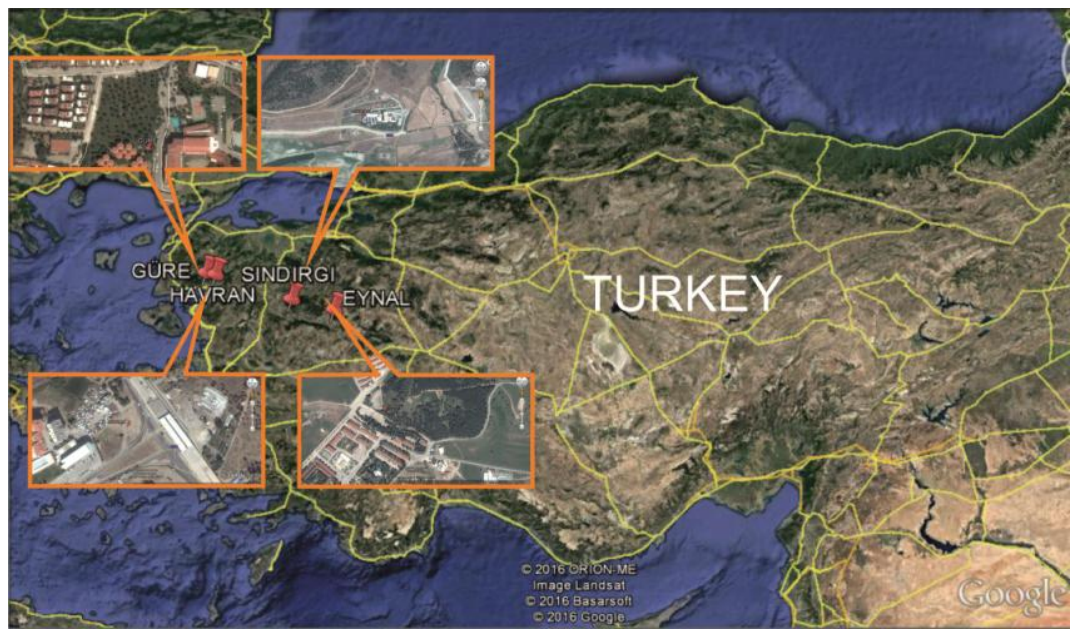

Figure 2. Sampling locations were marked on the map. GPS coordinates of the sampling points

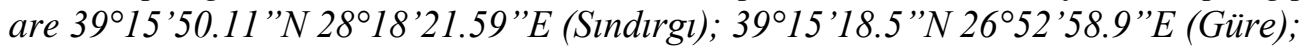

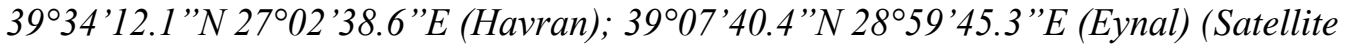
imagery: Google/Google Earth).

\section{Chemical analysis of thermal water samples}

Chemical analysis of water samples was performed with an ICP (Perkin Elmer Optical Emission Spectrofotometer Optima 4300 DV). Na, K, Mg, Ca, Mn, and Fe were detected. 


\section{Fluorescence In Situ Hybridization (FISH) analysis of thermal water samples}

For fixation, $1.2 \mathrm{ml}$ formaldehyde (Sigma Aldrich) (37\%) was added to 5-ml water samples and incubated at $4{ }^{\circ} \mathrm{C}$ overnight. Then samples were filtered with a $0.2-\mu \mathrm{m}$ pore size GTTP filter (Milipore). For hybridization, we used 16S rRNA targeted oligonucleotide probes with a Cy3-tagged Eub 338 and an Arc 344 universal probe. Hybridization was carried out at $46^{\circ} \mathrm{C}$ for $2.5 \mathrm{~h}$. Next, filters were washed with washing buffer and stained DNA-specific fluorescent DAPI dye, rinsed ethyl alcohol, distilled water, and finally analyzed with a Leica DMIRE2 epifluorescence microscope (Anton et al., 1999).

\section{DNA extraction from pure cultures and water samples}

The bacterial genomic DNA from purified cultures were prepared using the protocol described by the ZR Fungal/Bacterial DNA MicroPrep ${ }^{\mathrm{TM}}$ Kit. To obtain total bacterial genomic DNA, water samples (2 liters) were filtered with $0.2-\mu \mathrm{m}$ pore size filters (Millipore). DNA extraction from filters was performed according to Boutte et al. (2005). Extracted DNA was stored at $-85^{\circ} \mathrm{C}$ until used.

\section{Cloning of $16 \mathrm{~S}$ rDNA}

The water samples were used for cloning. PCR amplification of the 16S rRNA gene was done in a $3 \times 50 \mu \mathrm{l}$ mixture with a set of universal primers: $27 \mathrm{~F}$ (AGAGTTTGATCMTGGCTCAG), 21F (TCCGGTTGATCCYGCCGG), and 1492R (TACGGYTACCTTGTTACGACTT) (Nakagawa et al., 2002; Antoniou et al., 2015). PCR reactions were carried out with an Applied Biosystems ${ }^{\circledR}$ thermal cycler under the following conditions: $25 \mu$ l OneTaq ${ }^{\circledR} 2 X$ Master Mix with Standard Buffer (New England Biolabs, Inc), $0.2 \mu \mathrm{M}$ of the forward and reverse primers, and $2 \mu 1$ DNA in a final volume of $50 \mu 1$. Amplification was carried out as follows: one cycle of $3 \mathrm{~min}$ at $94^{\circ} \mathrm{C} ; 30$ cycles of $30 \mathrm{~s}$ at $94^{\circ} \mathrm{C}, 1 \mathrm{~min}$ at $55^{\circ} \mathrm{C}$, and $1 \mathrm{~min}$ at $72^{\circ} \mathrm{C}$; and a final elongation step of $10 \mathrm{~min}$ at $72^{\circ} \mathrm{C}$. PCR products were purified with Wizard ${ }^{\circledR}$ SV Gel and a PCR Clean-Up System. Poly (A) extension was performed using a Qiagen ${ }^{\circledR}$ A-Addition kit according to the manufacturer's instructions. Cloning of the PCR products was done with a Qiagen PCR Cloning plus kit following the manufacturer's instructions. White and light blue transformants were purified twice by streaking and then were screened by performing colony PCR with the primer pairs M13F (5'-GTAAAACGACGGCCAGT-3') and M13R (5'-GTTTTCCCAGTCACGAC3 '). The amplification conditions were those described in by Piterina et al. (2010). Primers were subjected to Amplified Ribosomal DNA Restriction Analysis (ARDRA) to screen the clone libraries.

\section{ARDRA (Amplified Ribosomal DNA Restriction Analysis)}

The 16S rRNA gene amplicons obtained from the genomic DNA of the isolates and clones were used for ARDRA with the restriction endonuclease MboI (MBI Fermentas) (Table 1). The digestion reaction was prepared according to the manufacturer's instructions. ARDRA patterns were compared and identical patterns were considered to be from the same group. Partial sequences of 16S rDNAs from representatives of each group were determined. For each ARDRA type, sequencing was carried out with primers 1492R (5'-GTACGGCTACCTTGTTACGAC-3') and 907R (5'CCGTCAATTCMTTTRAGTTT-3') (Lane et al., 1985) by Macrogen (Seoul, Korea) and then these sequences were assembled. Environmental 16S rRNA gene sequences 
from the hot springs were deposited in the GenBank with these accession numbers: KR864865, KR864866, KR864867, KR864868, KR864869, KR864870, KR864871, KR864872, KR864873, KR864874, KR864875, KR864876, KR864877, KR864878, KR864879, KR864880, KR864881, KR864882, KR864883, KT893400, KT893401.

\section{Analyses of sequence data}

All sequences were compared with the BLAST search program on the National Center for Biotechnology Information website (http://www.ncbi.nlm.nih.gov). The top five hits as well as some additional relevant sequences were used for phylogenetic analysis. 16S rRNA sequences from hits of our sequences were obtained through the RDP (Ribosomal Database Project) site at Michigan State University (http://rdp.cme.msu.edu/). Sequences of partial 16S rDNA of cultures and clones were analyzed with the MEGA 6.0 program (Tamura et al., 2007). All sequences were checked for chimera formation using DECIPHER (ES Wright et al., 2012). The CHECK-CHIMERA program, developed by the Ribosomal Database Project, and the phylogenetic affiliations of their $5^{\prime}$ and $3^{\prime}$ ends were compared.

\section{Phylogenetic analysis}

Sequences obtained from the isolates and clones were aligned with the closest strains and retrieved from environmental samples obtained from RDP II and NCBI. Phylogenetic trees were constructed using the MEGA 6.0 program. The Distance Matrix was calculated using the Jukes-Cantor algorithm and the trees were constructed using the Nearest-Neighbor-Interchange (NNI) method. Validity of tree topology was evaluated with the bootstrap method (1000 replicates).

\section{Results and Discussion}

\section{Chemical properties of the water samples}

Thermal water samples of the springs had different chemical properties, but $\mathrm{pH}$ was about 7.13-8.04 in all springs. Chemical analysis of the thermal waters shows that they are neutral and slightly alkaline. $\mathrm{Na}(1054 \mathrm{ppm}), \mathrm{Mg}(12.23 \mathrm{ppm}), \mathrm{Ca}$ (42.34 ppm), Fe (1.7 $\mathrm{ppm})$, and $\mathrm{K}(66.38 \mathrm{ppm})$ ions were highest in the Eynal spring whereas Mn ions (0.03 ppm) were highest in the Güre spring. Each water sample had different chemical properties because of the temperature differences of the sources and geological structure of the schist.

\section{Culture identifications}

In total, we obtained 66 pure isolates with different morphologies on agar plates. Like the Gram reaction, 66 isolates were Gram positive bacilli. Their colony colors were white, cream, and yellow and some of them had a mucoid structure. These isolates had 20 different ARDRA profiles with the MboI restriction enzyme. ARDRA profiles of the isolates and their closest Genbank matches are shown in Table 1.

The Eynal hot spring is more diverse, with 10 different ARDRA profiles and 8 that were not in other springs. According to the cultivation result, Bacillus sp. and Geobacillus sp. were most abundant in all springs. The Aeribacillus genus was obtained from only the Eynal hot spring. Group 13 has most isolates whereas groups 3, 6, 8, 10, $11,14,15$, and 20 were represented by only 1 isolate each. 
Table 1. Thermophilic isolates and their closest GenBank matches.

\begin{tabular}{|c|c|c|c|c|}
\hline \multirow{2}{*}{$\begin{array}{l}\text { ARDRA } \\
\text { Group No }\end{array}$} & \multirow{2}{*}{$\begin{array}{l}\text { Isolate Code * } \\
(\text { GenBank No) } \\
\end{array}$} & \multicolumn{3}{|c|}{ Closest GenBank Match } \\
\hline & & $\begin{array}{c}\% \text { of identity } \\
\text { with the closest relative }\end{array}$ & $\begin{array}{l}\text { Closest relative } \\
\text { according to BLAST search/Length }\end{array}$ & Accession no./Source \\
\hline 1 & $\begin{array}{c}\mathrm{S} 2 \\
(\mathrm{KR} 864865)\end{array}$ & $99 \%$ & Geobacillus thermoleovorans/1434 & $\begin{array}{l}\text { NR074931/ } \\
\text { United Kingdom hot spring }\end{array}$ \\
\hline 2 & $\begin{array}{c}\text { S5 } \\
(\mathrm{KR} 864881)\end{array}$ & $100 \%$ & Geobacillus thermoparaffinivorans/1291 & $\begin{array}{l}\text { KT266806/ } \\
\text { China Fujian hot spring }\end{array}$ \\
\hline 3 & $\begin{array}{c}\text { E4 } \\
(\mathrm{KR} 864882)\end{array}$ & $99 \%$ & Geobacillus thermoleovorans/1457 & $\begin{array}{l}\text { AJ564612/ } \\
\text { United Kingdom hot spring }\end{array}$ \\
\hline 4 & $\begin{array}{c}\text { E6 } \\
(\mathrm{KR} 864883)\end{array}$ & $99 \%$ & Geobacillus kaustophilus/1211 & $\begin{array}{l}\text { FJ823105/ } \\
\text { Lakeshore duff }\end{array}$ \\
\hline 5 & $\begin{array}{c}\mathrm{G} 1 \\
(\mathrm{KR} 864876)\end{array}$ & $100 \%$ & Bacillus licheniformis/1353 & $\begin{array}{l}\text { KF879248 / } \\
\text { Morocco hot spring }\end{array}$ \\
\hline 6 & $\begin{array}{c}\mathrm{G} 2 \\
(\mathrm{KT} 893401)\end{array}$ & $99 \%$ & Brevibacillus thermoruber $/ 1304$ & $\begin{array}{l}\text { KJ842630/ } \\
\text { Indonesia hot spring }\end{array}$ \\
\hline 7 & $\begin{array}{c}\text { G9 } \\
(\text { KR864879) }\end{array}$ & $100 \%$ & Bacillus licheniformis/1353 & $\begin{array}{l}\text { KF879248 / } \\
\text { Morocco hot spring }\end{array}$ \\
\hline 8 & $\begin{array}{c}\text { G5 } \\
\text { (KR864877) }\end{array}$ & $100 \%$ & Aneurinibacillus thermoaerophilus/1341 & $\begin{array}{l}\text { EF032876/ } \\
\text { Selangor }\end{array}$ \\
\hline 9 & $\begin{array}{c}\mathrm{H} 4 \\
(\mathrm{KR} 864869)\end{array}$ & $99 \%$ & Anoxybacillus flavithermus/1379 & $\begin{array}{l}\text { KJ722464/ } \\
\text { China Fujian hot spring }\end{array}$ \\
\hline 10 & $\begin{array}{c}\text { H6 } \\
(\mathrm{KR} 864870)\end{array}$ & $99 \%$ & Bacillus sp./1174 & $\begin{array}{l}\text { LN681603/ } \\
\text { Tapovan, India }\end{array}$ \\
\hline
\end{tabular}




\begin{tabular}{|c|c|c|c|c|}
\hline 11 & $\begin{array}{l}\mathrm{H} 7 \\
(\mathrm{KR} 864871)\end{array}$ & $99 \%$ & Aneurinibacillus sp./1123 & $\begin{array}{l}\text { FJ268961/ } \\
\text { Pendula leaf }\end{array}$ \\
\hline 12 & $\begin{array}{c}\mathrm{EY} \\
(\mathrm{KR} 864873)\end{array}$ & $97 \%$ & Geobacillus sp./1329 & $\begin{array}{l}\text { HQ703944/ } \\
\text { Manikaran hot spring }\end{array}$ \\
\hline 13 & $\begin{array}{c}\text { EY5 } \\
(\text { KR864866) }\end{array}$ & $100 \%$ & Bacillus sonorensis/1131 & $\begin{array}{l}\text { KP282741/ } \\
\text { Crude oil samples }\end{array}$ \\
\hline 14 & $\begin{array}{c}\text { EY13 } \\
(\mathrm{KR} 864874)\end{array}$ & $100 \%$ & Geobacillus thermoparaffinivorans/1369 & $\begin{array}{l}\text { KC252981/ } \\
\text { Benguet hot spring }\end{array}$ \\
\hline 15 & $\begin{array}{c}\text { EY18 } \\
\text { (KR864867) }\end{array}$ & $100 \%$ & Aeribacillus pallidus/1128 & $\begin{array}{l}\text { KR611619/ } \\
\text { Reservoir fromatiion water }\end{array}$ \\
\hline 16 & $\begin{array}{c}\text { EY21 } \\
(\text { KR864875) }\end{array}$ & $100 \%$ & Bacillus licheniformis/1284 & $\begin{array}{l}\text { KJ572278 / } \\
\text { Morocco hot spring }\end{array}$ \\
\hline 17 & $\begin{array}{c}\text { SY5 } \\
(\text { KR864880) }\end{array}$ & $100 \%$ & Bacillus licheniformis/1192 & $\begin{array}{l}\text { GU945232 / } \\
\text { Morocco hot spring }\end{array}$ \\
\hline 18 & $\begin{array}{c}\text { GY4 } \\
(\text { KR864868) }\end{array}$ & $99 \%$ & Anoxybacillus sp./1393 & $\begin{array}{l}\text { GQ184213/ } \\
\text { Sungai Klah hot spring }\end{array}$ \\
\hline 19 & $\begin{array}{c}\text { H9 } \\
(\text { KR864872) }\end{array}$ & $99 \%$ & Brevibacillus thermoruber $/ 1357$ & $\begin{array}{l}\text { KJ722521/ } \\
\text { Schoenebeck geothermal station }\end{array}$ \\
\hline 20 & $\begin{array}{c}\text { EY12 } \\
\text { (KT893400) }\end{array}$ & $100 \%$ & Bacillus licheniformis/1191 & $\begin{array}{l}\text { KF879248 / } \\
\text { Morocco hot spring }\end{array}$ \\
\hline
\end{tabular}

*S (Sındırgı), E (Eynal), G (Güre), H (Havran) 


\section{Uncultural molecular analysis based on the $16 \mathrm{~S}$ rRNA gene}

To determine the biodiversity of the thermal sources, we first cultivated water samples and identified those with 16S rRNA gene sequences. In addition, we used culture-independent methods, FISH and cloning. A total of 265 clones containing inserts of the right size were analyzed. First, they were grouped on the basis of their restriction profiles and then representatives from 15 different restriction groups were sequenced with the sequence primer 1492R. The best match to databases was obtained from BLAST analyses of the selected clones (Table 2). Most clones were from Group 1, related to Anoxybacillus flavithermus (99\% similarity). Groups 7 and 8 were also related to Anoxybacillus flavithermus, with $99 \%$ and $100 \%$ similarities.

Table 2. Clones and their closest GenBank matches.

\begin{tabular}{|c|c|c|c|c|}
\hline \multirow{2}{*}{$\begin{array}{l}\text { ARDRA } \\
\text { Group No }\end{array}$} & \multirow[t]{2}{*}{ Clone Code } & \multicolumn{3}{|c|}{ Closest GenBank Match } \\
\hline & & $\begin{array}{c}\% \text { of identity } \\
\text { with the closest } \\
\text { relative } \\
\end{array}$ & $\begin{array}{l}\text { Closest relative } \\
\text { according to BLAST } \\
\text { search/Length }\end{array}$ & Accession no./Source \\
\hline 1 & $\begin{array}{l}\text { Clone G1 } \\
\text { (KT893391) }\end{array}$ & $99 \%$ & $\begin{array}{l}\text { Anoxybacillus flavithermus } \\
\text { /792 }\end{array}$ & $\begin{array}{l}\text { KJ722464.1/ } \\
\text { Schoenebeck } \\
\text { station }\end{array}$ \\
\hline 2 & $\begin{array}{l}\text { Clone G7 } \\
\text { (KT893392) }\end{array}$ & $99 \%$ & Meiothermus silvanus $/ 906$ & $\begin{array}{l}\text { NR074273 / } \\
\text { Portugal hot spring }\end{array}$ \\
\hline 3 & $\begin{array}{l}\text { Clone G12 } \\
\text { (KT893393) }\end{array}$ & $95 \%$ & Uncultured bacterium /670 & $\begin{array}{l}\text { HQ639470.1/ } \\
\text { China }\end{array}$ \\
\hline 4 & $\begin{array}{l}\text { Clone H4 } \\
\text { (KT893394) }\end{array}$ & $93 \%$ & Uncultured bacterium /889 & $\begin{array}{l}\text { EF648061.1 / } \\
\text { Activated sludge-China }\end{array}$ \\
\hline 5 & $\begin{array}{l}\text { Clone H12 } \\
(\text { KT893395) }\end{array}$ & $99 \%$ & $\begin{array}{l}\text { Aneurinibacillus } \\
\text { thermoaerophilus } / 559\end{array}$ & $\begin{array}{l}\text { KJ190161.1 / } \\
\text { Activated sludge-China }\end{array}$ \\
\hline 6 & $\begin{array}{l}\text { Clone H13 } \\
\text { (KT893396) }\end{array}$ & $99 \%$ & $\begin{array}{l}\text { Brevibacillus thermoruber } \\
1826\end{array}$ & $\begin{array}{l}\text { KJ842631.1 / } \\
\text { China }\end{array}$ \\
\hline 7 & $\begin{array}{l}\text { Clone H15 } \\
\text { (KT893397) }\end{array}$ & $99 \%$ & $\begin{array}{l}\text { Anoxybacillus flavithermus } \\
1859\end{array}$ & $\begin{array}{l}\text { KJ842638.1/ } \\
\text { Tanjung Sakti Hot spring }\end{array}$ \\
\hline 8 & $\begin{array}{l}\text { Clone S12 } \\
\text { (KT893399) }\end{array}$ & $100 \%$ & $\begin{array}{l}\text { Anoxybacillus flavithermus } \\
\text { /809 }\end{array}$ & $\begin{array}{l}\text { KJ722464.1/ } \\
\text { Schoenebeck geother } \\
\text { station }\end{array}$ \\
\hline 9 & $\begin{array}{l}\text { Clone E21 } \\
(\text { KT893383) }\end{array}$ & $97 \%$ & Bacillus licheniformis /735 & $\begin{array}{l}\text { KP216563.1 / } \\
\text { High salt wastewater }\end{array}$ \\
\hline 10 & $\begin{array}{l}\text { Clone E25 } \\
(\text { KT893384) }\end{array}$ & $91 \%$ & Uncultured bacterium $/ 940$ & $\begin{array}{l}\text { HM184957 / } \\
\text { China }\end{array}$ \\
\hline 11 & $\begin{array}{l}\text { Clone E27 } \\
\text { (KT893385) }\end{array}$ & $98 \%$ & Geobacillus sp. $/ 484$ & $\begin{array}{l}\text { CP001638.1/ } \\
\text { Hot wood } \\
\text { Middleton }\end{array}$ \\
\hline 12 & $\begin{array}{l}\text { Clone E33 } \\
(\text { KT893386) }\end{array}$ & $91 \%$ & Meiothermus sp. $/ 565$ & $\begin{array}{l}\text { AY845055.1/ } \\
\text { Hot spring }\end{array}$ \\
\hline 13 & $\begin{array}{l}\text { Clone E36 } \\
\text { (KT893387) }\end{array}$ & $99 \%$ & $\begin{array}{l}\text { Bacillus amyloliquefaciens } \\
\text { /542 }\end{array}$ & $\begin{array}{l}\text { KR109267.1/ } \\
\text { Hot spring }\end{array}$ \\
\hline 14 & $\begin{array}{l}\text { Clone E41 } \\
(\text { KT893389) }\end{array}$ & $99 \%$ & Uncultured organism /837 & $\begin{array}{l}\text { HQ767379.1 / } \\
\text { Gastrointestinal specimens }\end{array}$ \\
\hline 15 & $\begin{array}{l}\text { Clone E42 } \\
\text { (KT893390) }\end{array}$ & $99 \%$ & Geobacillus sp. $/ 883$ & $\begin{array}{l}\text { CP001638.1/ } \\
\text { Hot wood } \\
\text { Middleton } \\
\end{array}$ \\
\hline
\end{tabular}


The Eynal hot spring had the most diversity. Groups 9-15 were only found at Eynal. Groups 1 and 2 were present in all hot springs whereas Groups 3 and 8 were found only in the Güre and Sindirgı hot springs, respectively.

The sequences of clone G12, H4, and E25 were related to Uncultured bacterium (Acc. Number HQ639470; EF648061; HM184957) and Clone G7 and E33 were affiliated with Meiothermus silvanus (Acc. Number NR074273) and Meiothermus sp. (Acc. Number AY845055). Clone H12, H13, and E21 were related to Aneurinibacillus thermoaerophilus (Acc. Number KJ190161), Brevibacillus thermoruber (Acc. Number KJ842631), and Bacillus licheniformis (Acc. Number KP216563), respectively. Clone E27 and E42 were affiliated with Geobacillus sp. (Acc. Number CP001638). Clone E36 and 41 were related to Bacillus amyloliquefaciens (Acc. Number KR109267.1) and Uncultured organism (Acc. Number HQ767379), respectively.

\section{Phylogenetic trees}

Phylogenetic analysis was performed using the maximum likelihood treeing algorithm in the MEGA 6.0 program. Phylogenetic trees for bacteria constructed based on partial 16S rRNA sequences are shown Figures 3 and 4.

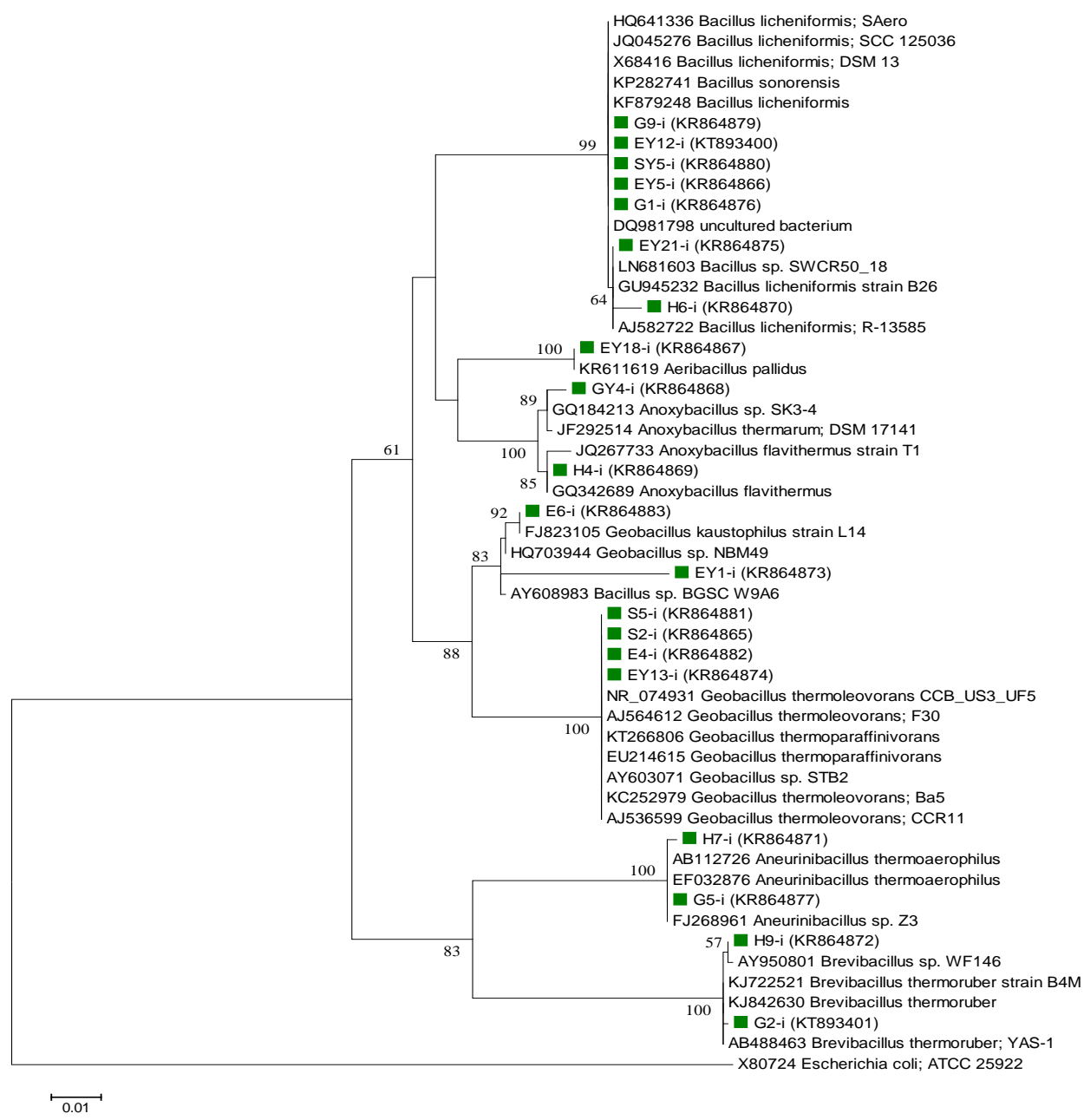

Figure 3. Phylogenetic inferences based on 16S rRNA gene sequences from isolates (indicated by green squares). The scale bar represents the expected number of substitutions per site. Bootstrap support values below $50 \%$ were not included in the figure. 


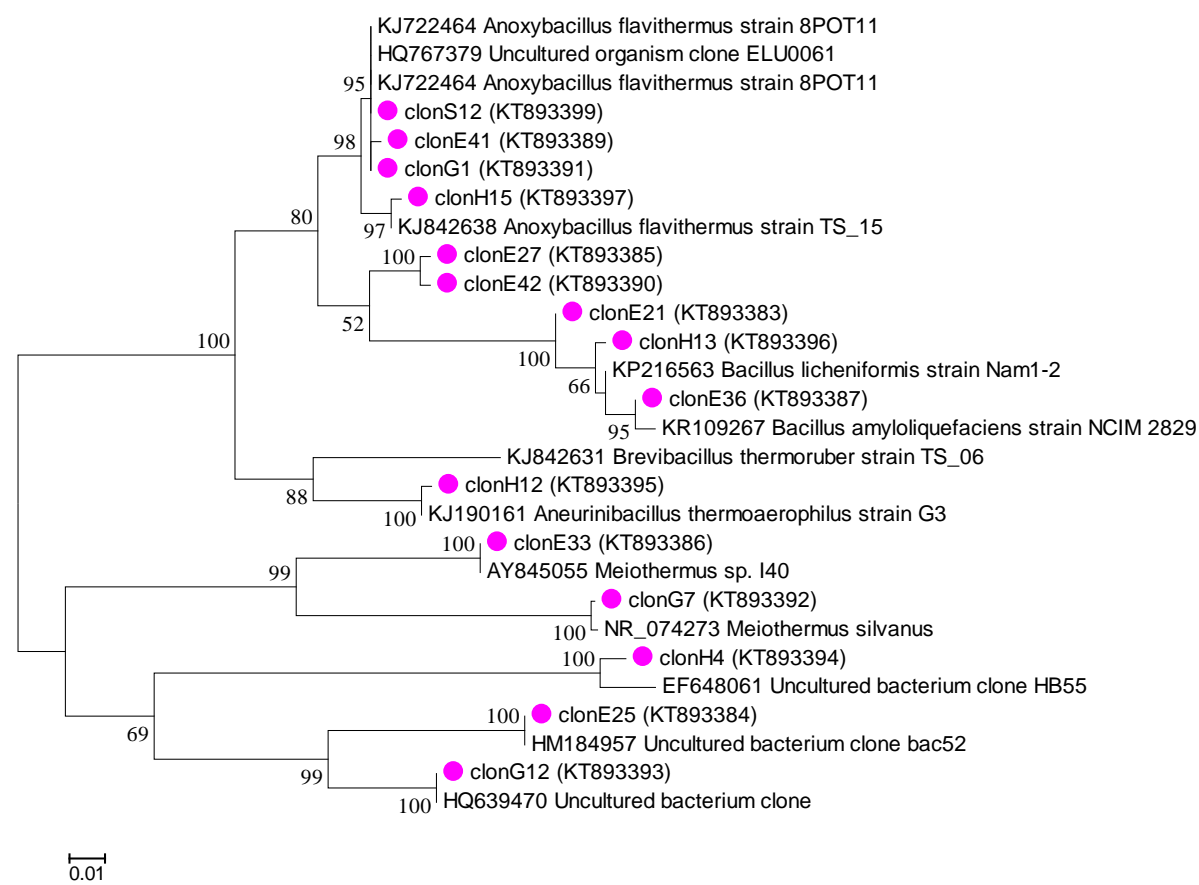

Figure 4. Phylogenetic inferences based on $16 S$ rRNA gene sequences from clones (indicated by pink circles) belonging to the bacteria. The scale bar represents the expected number of substitutions per site. Bootstrap support values below $50 \%$ were not included in the figure.

\section{FISH Analysis}

FISH analysis of the hot springs' prokaryotic communities showed that bacterial species were dominant. The signals of the bacteria specific Eub 338 probe showed that Eynal hot spring had the most species. Long and short bacilli were dominant in all springs (Figure 5). Also, there were cells with long chain morphology and spontaneous radiation. These cells were most probably a member of the Cyanobacteria.

In agreement with the culture and cloning results, the FISH results showed that bacilli morphology was abundant in all hot springs.
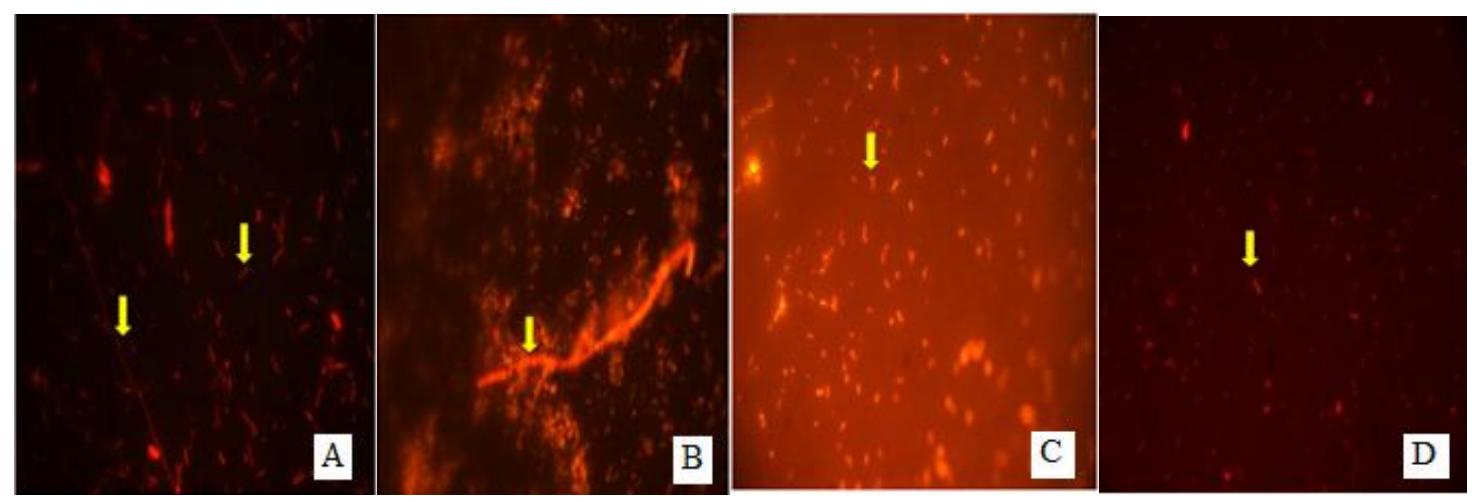

Figure 5. A. Eub 338 positive cells with thin bacilli morphology from the Sindirg hot spring.

B. Autoflourescent chain cell from the Eynal hot spring. C. Eub 338 positive cells with thin, twisted bacilli morphology from the Güre hot spring. D. Eub 338 positive cells with thin, twisted bacilli morphology from the Havran hot spring. 


\section{Conclusions}

Since 16S rRNA is the best conserved part of the 30S rRNA operon, it has been proposed as an "evolutionary clock," which has led to the reconstruction of the tree of life (Woese, 1987). The 16S sequence analysis is used to identify and classify isolated pure cultures and estimate bacterial diversity in environmental samples without culturing through metagenomic approaches. The cloning and sequencing of $16 \mathrm{~S}$ genes amplified directly from extreme environments through metagenomic approaches has demonstrated that microbial diversity is far more extensive than we ever imagined from culture-based studies alone. Culture methods continue to improve to reveal the exact diversity (Janssen et al., 2002; Lopez-Garcia and Moreira, 2008). The ARDRA is a technique based on the cutting with restriction enzymes of $16 \mathrm{~S}$ rRNA gene region after amplification with appropriate primers. Restriction profiles obtained by cutting with restriction enzymes are chosen as representative of different species (Sklarz et al., 2009).

Our thermophilic isolates have high similarities to previously cultured thermophilic bacteria such as Aneurinibacillus, Aeribacillus, Anoxybacillus, Bacillus, Brevibacillus, and Geobacillus, which were obtained from the Gene-Bank (Canganella and Trovatelli, 1995; Nazina et al., 2004; Yasawong et al., 2011; Özdemir et al., 2012; İnan et al., 2012).

The species Meiothermus silvanus, Aneurinibacillus thermoaerophilus, and Bacillus amiloliquefaciens were only detected using cloning and the species Geobacillus thermoleovorans, Geobacillus thermoleovorans, Geobacillus thermoparaffinivorans, Bacillus sonorensis, Aeribacillus pallidus, and Geobacillus kaustophilus were obtained only from the culture studies.

Aneurinibacillus, Aeribacillus, Anoxybacillus, Bacillus, Brevibacillus, Geobacillus, Thermus, Pseudoxanthomonas, Acinetobacter, Paenibacillus, and Thermoactinomycetes were found in earlier studies from different hot springs (Palmisano et al., 2001; Adigüzel et al., 2009; Ghati et al., 2013). Although Geobacillus and Bacillus species were dominant in our samples, Thermus, Pseudoxanthomonas, Acinetobacter, Paenibacillus, and Thermoactinomycetes species were not encountered in our culture and cloning studies.

This is the first study to reveal the diversity of the Güre, Havran, Sindırg1, and Eynal hot springs. Culture-dependent and culture-independent techniques were used simultaneously to target unique regions of the 16S rRNA gene. The isolates obtained in this study have potentially important biotechnological applications because their industrial enzymes are resistant to harsh conditions. These abilities of our isolates will be investigated in future projects.

Acknowledgments. The authors would like to thank Anadolu University Research Project Department, Project 1403F100. 


\section{REFERENCES}

[1] Adiguzel, A., Ozkan, H., Baris, O., Inan, K., Gulluce, M., Şahin, F. (2009): Identification and characterization of thermophilic bacteria isolated from hot springs in Turkey -Journal of Microbiological Methods 79: 321-328.

[2] Akkaya, E.S., Kıvanç, M. (2002): Microbiological analyses of wafers and biscuits obtained from two different factories in Eskişehir -2nd World Engineering Congress, Sarawak, Malaysia 165-168.

[3] Anton, J., Llobet-Brossa, E., Rodriguez-Valera, F., Amann, R. (1999): Fluorescence in situ hybridization analysis of the prokaryotic community inhabiting crystallizer ponds Environmental Microbiology 1: 517-523.

[4] Antoniou, E., Fodelianakis, S., Korkakaki, E., Kalogerakis, N. (2015): Biosurfactant production from marine hydrocarbon-degrading consortia and pure bacterial strains using crude oil as carbon source -Frontiers in Microbiology 6: 274.

[5] Boutte, C., Komárková, J., Grubisic, S., Znachor, P. (2005): A polyphasic approach to assess the cyanobacterial diversity of summer samples from Czech reservoirs Algological Studies 117:177-195.

[6] Canganella, F., Trotavelli, L.D. (1995): Ecological and physiological studies on thermophilic bacilli from sulfataric hot springs of central Italy -Journal of Basic Microbiology 35(1), 9-19.

[7] Demirjian, D.C., Mori`s-Varas, S., Cassidy, C.S. (2001): Enzymes from extremophiles, Current Opinion in Chemical Biology 5:144-151.

[8] ES Wright et al (2012): DECIPHER, A search-based approach to chimera identification for 16S rRNA sequences -Applied and Environmental Microbiology.

[9] Ghati, A., Sarkar, K., Paul, G. (2013): Isolation, characterization and molecular identification of esterolytic thermophilic bacteria from an Indian hot spring -Current Research in Microbiology and Biotechnology 1(4): 196-202.

[10] İnan, K., Çanakçı, S., Belduz, A.O., Şahin, F. (2012): Brevibacillus aydinogluensis sp. nov., a moderately thermophilic bacterium isolated from Karakoç hot spring International Journal of Systematic and Evolutionary Microbiology 62: 849-855.

[11] Janssen, P.H., Yates, P.S., Grinton, B.E., Taylor, P.M., Sait, M. (2002): Improved culturability of soil bacteria and isolation in pure culture of novel members of the divisions Acidobacteria, Actinobacteria, Proteobacteria, and Verrucomicrobia - Applied and Environmental Microbiology 68: 2391-6.

[12] Kardos, L., Juhász, Á., Palkó, GY., Oláh, J., Barkács, K., Záray, GY. (2011): Comparing of mesophilic and thermophilic anaerobic fermented sewage sludge based on chemical and biochemical tests -Applied Ecology and Environmental Research 9(3): 293-302.

[13] Lane, D.J., Pace, B., Olsen, G.J., Stahl, D.A., Sogin, M.L., Pace, N.R. (1985): Rapid determination of $16 \mathrm{~S}$ ribosomal RNA sequences for phylogenetic analyses. Proceedings of the National Academy of Sciences of the USA 82:6955-9.

[14] Lopez-Garcia, P., and Moreira, D. (2008): Tracking microbial biodiversity through molecular and genomic ecology - Research in Microbiology 159:67-73.

[15] Nakagawa, T., Hanada, S., Maruyama, A., Marumo, K., Urabe, T., Fukui, M. (2002): Distribution and diversity of thermophilic sulfate-reducing bacteria within a $\mathrm{Cu}-\mathrm{Pb}-\mathrm{Zn}$ mine (Toyoha, Japan) -FEMS Microbiology Ecology 41: 199-209.

[16] Nazina, T.N., Lebedeva, E.V., Poltaraus, A.B. (2004): Geobacillus gargensis sp. nov., a novel thermophile from a hot spring, and the reclassification of Bacillus vulcani as Geobacillus vulcani comb. nov. -International Journal of Systematic and Evolutionary Microbiology 54: 2019-2024.

[17] Özdemir, S., Matpan, F., Okumus, V., Dündar, A., Ulutas, M.S., Kumru, M. (2012): Isolation of a thermophilic Anoxybacillus flavithermus sp. nov. and production of thermostable $\alpha$-amylase under solid-state fermentation (SSF) -Annals of Microbiology 62: $1367-1375$. 
[18] Palmisano, M.M., Nakamura, L.Kk, Duncan, K.E., Istock, C.A., Cohan, F.M. (2001): Bacillus sonorensis sp. nov., a close relative of Bacillus licheniformis, isolated from soil in the Sonoran Desert, Arizona -International Journal of Systematic and Evolutionary Microbiology 51(5): 1671-1679.

[19] Piterina, A.V., Bartlett, J., Pembroke, J.T. (2010): Molecular analysis of bacterial community DNA in sludge undergoing Autothermal Thermophilic Aerobic Digestion (ATAD): Pitfalls and Improved Methodology to Enhance Diversity Recovery. -Diversity 2: 505-526.

[20] Rifaat, H.M., Nagieb, Z.A., Ahmed, Y.M. (2005): Production of Xylanases by Streptomyces species and their bleaching effect on rice straw pulp -Applied Ecology and Environmental Research 94(1): 151-160.

[21] Sklarz, M.Y., Angel, R., Gillor, O., Soares, M.I.M. (2009): Evaluating amplified rDNA restriction analysis assay for identification of bacterial communities -Antonie Van Leeuwenhoek 96: 659-664.

[22] Tamura, K., Dudley, J., Nei, M., Kumar, S. (2007): MEGA4: Molecular evolutionary genetics analysis (MEGA) software version 4.0 -Molecular Biology and Evolution 24: 1596-1599.

[23] Woese, C.R. (1987): Bacterial evolution -Microbiological Reviews 51(2): 221-271.

[24] Yasawong, M., Areekit, S., Pakpitchareon, A., Santiwatanakul, S., Chansiri, K. (2011): Characterization of thermophilic halotolerant Aeribacillus pallidus td1 from Tao Dam hot spring, Thailand -International Journal of Molecular Sciences 12:5294-5303. 